\title{
ANALISIS SEKTOR POTENSI DAN PENDORONG EKONOMI KABUPATEN BLITAR PROVINSI JAWA TIMUR TAHUN 2014-2019
}

\author{
${ }^{1}$ Dwi Reza Khusnul Khuluk, ${ }^{2}$ Ignatia Martha Hendarti \\ ${ }^{1}$ Fakultas Ekonomi dan Bisnis / Universitas Pembangunan \\ Nasional Veteran Jawa Timur , ${ }^{2}$ Fakultas Ekonomi dan \\ Bisnis / Universitas Pembangunan Nasional Veteran Jawa \\ Timur Alamat e-mail : dwirezakhusnul21@gmail.com
}

\begin{abstract}
Economic development is an effort made by local governments to improve the welfare of the community, to improve regional economic development is necessary to develop economic sectors in policies used by local governments. The research aims to analyze how the potential of economic sector and sector that is the driver of economic growth in Blitar Regency, East Java Province, in this study used Location Quotient (LQ) analysis method and Shift Share (SS) analysis. The data used is secondary data obtained from central statistics agency East Java and using vulnerable people from 2014 to 2019, from this research obtained results that economic growth in Blitar regency is quite fast and in its development has experienced many ups and downs in the base and non-base sectors. The most potential sector is the accommodation and food supply sector.
\end{abstract}

Keywords: Shift-share (SS), Location Quotient (LQ), Potensi Daerah.

\begin{abstract}
ABSTRAK
Pembangunan ekonomi merupakan sebuah upaya yang dilakukan pemerintah daerah untuk meningkatkan kesejahteraan masyarakat, untuk meningkatkan pembangunan ekonomi wilayah maka diperlukan pengembangan sektor ekonomi dalam kebijakan yang digunakan oleh Pemerintah Daerah. Penelitian bertujuan untuk menganalisis bagaimana potensi sektor ekonomi dan sektor yang menjadi pendorong pertumbuhan ekonomi di wilayah Kabupaten Blitar Provinsi Jawa Timur, dalam penelitian ini mengguanakan metode analisis Location Quetiont (LQ) and analisis Shift Share (SS). Data yang digunakan merupakan data sekunder yang didapatkan dari BPS dan menggunakna rentan waktu 2014 sampai dengan 2019, dari penelitian ini diperoleh hasil bahwa pertumbuhan ekonomi yang ada di Kabupaten Blitar termasuk yang cukup cepat dan dalam perkembangannya banyak mengalami naik turun dalam sektor basis dan non basisnya. Sektor yang paling berpotensi merupakan sektor penyediaan akomodasi dan makanan
\end{abstract}

Kata kunci : Shift-share (SS), Location Quetiont (LQ), Potensi Daerah. 


\section{PENDAHULUAN}

Setiap kabupaten/kota memiliki kewenangan sendiri dalam menentukan kebijakan dalam melakukan pembangunan daerah sebagai bentuk dari otonomi daerah yang telah dilaksanakan, menurut Undang-undang no. 22 tahun 1999 yang diganti dengan Undang-undang no. 32 tahun 2004 tentang pemerintahan daerah, setiap pemerintah daerah mempunyai kewenangan yang lebih luas untuk mengatur dan mengelola berbagai utusan penyelanggaraan pemerintahan bagi kepentingan dan kesejahteraan masayarakat daerah yang bersangkutan. Dalam melakukan pembangunana daerah pemerintah daerah menyesuaikan serta memeperhatikanpotensi dan keanekaragamna daerah karena pada dasarnya tiap daerah memilki karakter sosial, geografis, budaya yang berbeda, oleh karena itu kebijakan yang dilakukan pemerintah diharapkan mampu mencapai hasil yang maksimal, sehingga dapat memberikan timbal balik yang baik pula untuk pertumbuhan ekonomi daerah, dimana pertumbuhan ekonomi merupaakan salah satu tolak ukur untuk melihat bagaimana keberhasilan pembangunan ekonomi daerah.Kabupaten Blitar merupakan salah satu kabupaten Jawa Timur yang pada tahun 2018 mmepunyai laju perumbuhan ekonomi sebesar $5,01 \%$ lebih rendah dari tahun sebelumnya yakni sebesar $5,07 \%$.

Tabel. 1

\begin{tabular}{|c|c|c|}
\hline \multicolumn{3}{|c|}{ PDRB KAB. BLITAR } \\
\hline 2014 & 19920156.53 & 5.02 \\
\hline 2015 & 20928474.26 & 5.06 \\
\hline 2016 & 21991428.19 & 5.08 \\
\hline 2017 & 23107483.85 & 5.07 \\
\hline $2018^{*}$ & 24286240.89 & 5.01 \\
\hline
\end{tabular}

Sumber; BPS Kab. Blitar,2020

Melalui tabel tersebut dapat diketahui bahwa pertumbuhan PDRB Kab. Blitar pada tahun 2014-2018 berada di kisaran 5\% dimana angka ini termasuk angka yang cukup tinggi, namun angka ini masih terbilang lebih rendah dibandingkan dengan daerah tetangga yaitu Kabupaten Kediri dan Kabupaten Tulungagung. selama ini Kabupaten Blitar bertumpu pada sektor pertanian yang memberikan sumbangsih terbesar dalam PDRB Kabupaten Blitar mencapai 47,9\%pada tahun 2011, namun sektor pertanian ini juga berganutng pada gejolak alam sehingga perlu penanganan khusus, pada tahun 2017 sektor pertanian yang ada di Kabupaten Blitar mengalami penigkatan di beberapa komoditi seperti padi yang meningkat sebesar $3,12 \%$ dengan total produksi sebesar 423.485 ton. Komoditi jagung mengalami peningkatan produksi yang cukup tinggi sebesar $7,4 \%$ dengan total produksi sebesar 565.035 ton, selain itu juga nanas merupakan salah satu komoditi khas namun komoditi nanas mengalami penurunan produksi sebesar $-3,5 \%$ dengan penruurnan sebesar 11,978 ton. Melihat hal tersbut diamana Kabupaten Blitar masih bergantung pada satu sektor saja maka perlu dilakukan penelitian yang lebih lanjut mnegenai potensi sektor unggulan bagi Kabupaten Blitar, sehingga nantinya dapat meningkatkan pertumbuhan ekonomi daerah dan meningkatkan kesejahteraan masyarakat sehingga menunjukkan bahwa pembangunan ekonomi daerah Kabupaten Blitar.

\section{LANDASAN TEORI Potensi Ekonomi Daerah}

Suparmoko (2002) mendefinisikan Potensi Ekonomi Daerah sebagai kemampuan ekonomi daerah yang mungkin dan layak dan dikembangkan sehingga akan terus berkembang menjadi sumber penghidupan rakyat setempat bahkan dapat pertumbuhan ekonomi daerah secara keseluruhan utnuk berkembang denngan sendirinya dan berkesinambungan. Sumihardjo (2008) menjelaskan bahwa sektor unggulan yang dimiliki daerah telihat pada visi misi daerah yang tertuangdalam Rencana Pembangunan Jangka Panjang (RPJP) dan Rencana Pembangunan Jangka Menengah (RPJMD) setiap daerah, didalam kedua hal tersebut di muat bidang-bidang prioritas yang ada di daerah tersebut yang digunakan untuk memperkuat sektor 
unggulan daerah..

\section{Pertumbuhan Ekonomi}

Boediono (1999) menjelaskan pertumbuhan ekonomi merupakan sebuah proses kenaikan output perkapita dalam jangka panjang, jadi dalam pertumbuhan sekonomi sangat tergantung dengan output perkapita, dimana hal ini ada dua hal yang ahrus diperhatikan yaitu total output dan jumlah penduduk diwilayah tersebut. Menurut todaro terdapat 3 faktor dalam pertumbuhan ekonomi yaitu :

- Akumulasi Modal (capital accumulation), meliputi semua jenis investasi baru yang ditanamkan pada pabrik baru, tanah, perlatan fisik, dan pembagian sumber daya manusia yang juga ditingkatkan kualitasnya sehingga nantinya dapat membawa dampak positif yang sama terhadap angka produksi

- Pertumbuhan penduduk (Growth In Population), dengan meningkatnya pertumbuhan penduduk yang nantinya juga di ikuti oleh meningkatnya pertumbuhan tenaga kerja sebagai salah satu faktor positif yang memacu pertumbuhan ekonomi daerah, yang berarti semakin meningkatnya tenaga kerja akan meningkatkan tingkat produktifitas,

- Kemajuan teknologi (technological progress) merupakan sumber pertumbuhan ekonomi yang paling penting dimasa modern ini karena dengan kemajuan teknologi akan ditemukan cara baru ataupun teknologi baru untuk menggantikan cara-cara lama sehingga dapat meningkatkan pertumbuhan ekonomi dengan cepat.

Untuk mengukur besarnya pertumbuhan ekonomi dapat dihitung dengan :

\section{Pembangunan Ekonomi}

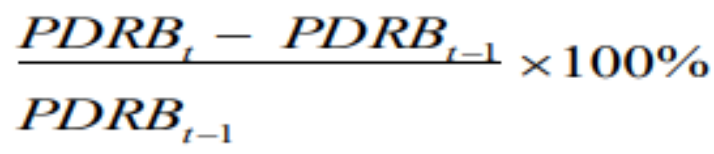

Menurut Lincolin Arsyad (2010) Pembangunan ekonomi daerah adalah suatu proses pemerintah daerah serta masyarakat mengelola sumber daya yang ada lalu membentuk suatu pola kemitraan antara pemerintah daerah dengan sektor swasta untuk menciptakan suatu lapangan kerja baru dan merangsang perkembangan kegiatan ekonomi (pertumbuhan ekonomi) dalam wilayah tersebut, pembangunan ekonomi daerah mencakup berbagai kegiatan amupu kebijakan yang dilakukan pemerintah daerah untuk melakukan pembangunan yang dapat mendorong pertumbuhan ekonomi, seperti melakukan pembangunan industru-industri alternatif atau mengembangan industry yang ada di wilayah tersebut, melakukan perbaikan kapasitas tenaga kerja yang ada di daerah tersebut sehingga dapat menghasilkan SDM yang lebih baik, setiap upaya pembangunan ekonomi memiliki tujuan untuk meningkatkan jumlah dan jenis peluang kerja bagi masyarakat. Hess dan Ross (1997) serta Blackman et a.I (2001) menjelaskan bahwa bahwa keberhasilan pembangunan ekonomi dapat dilihat dari perpaduan antara pertumbuhan ekonomi dan pengembangan ekonomi.

\section{METODOLOGI}

Jenis penellitian yang digunakan dalam penelitian ini adalah penelitian deskriptid dengan menggunakna pendekatan kuantitatif yang menggunakan data time series tahun 2014-2019 dengan objek penelitian Kabupaten Blitar. Metode yang digunakan adalah Location Quotient (LQ) dan Shift Share (SS).

\section{Location Quotient (LQ)}

Metode LQ sigunakan untuk mnegtahui seberapa besar tingkat spesialisasi sektor yang menjadi sektor unggulan daerah, dalam pengerjaannya LQ digunakan dengan cara membandingkan sektro tertentu yang ada di daerah dengan provinsi dengan total PDRB daerah dibagi dengan PDRB PrivinsiTeknik analisis yang digunakan untuk menentukan kategori suatu 
sektor termasuk dalam sektor basis atau bukan basis. Cara perhitungan dari teknik analisis LQ adalah :

$$
\text { LQJi }=\frac{\text { VAJi / VAli }}{\text { PDRBJ/PDRBI }}
$$

\section{Shift Share (SS)}

Analisis Shift Share digunakan untuk menghitung tingkat pertumbuhan yang ada di masing-masing daerah, selnajutnya analiss SS akan mengidentifikasi keuntungan lokasi dan struktur pertumbuhan ekonomi.

Untuk menghitung Shift Share dimulai dengan perhitungan perubahan PDRB sektor di suatu daerah antara 2 waktu, yaitu:

$$
\begin{aligned}
\Delta \mathrm{Qtij} & =\mathrm{Qtij}-\mathrm{Q} 0 \mathrm{ij} \\
\Delta Q_{i j}^{t} & =Q_{i j}^{0}\left\{\frac{Y_{t}}{Y_{0}}-1\right\}+Q_{i j}^{0}\left\{\frac{Q_{i}^{t}}{Q_{1}^{0}}-\frac{Y_{t}}{Y_{0}}\right\}+Q_{i j}^{0}\left\{\frac{Q_{i j}^{t}}{Q_{i j}^{0}}-\frac{Q_{i}^{t}}{Q_{i}^{0}}\right\}
\end{aligned}
$$

Persamaan ke 2 dapat dibedakan menjadi 3 komponen utama yang mempengaruhi pertumbuhan ekonomi daerah:

$$
\begin{aligned}
& P R_{i j}=Q_{i j}^{0}\left\{\frac{Y_{t}}{Y_{0}}-1\right\} \\
& P S_{i j}=Q_{i j}^{0}\left\{\frac{Q_{i}^{t}}{Q_{i}^{0}}-\frac{Y_{t}}{Y_{0}}\right\} \\
& D S_{i j}=Q_{i j}^{0}\left\{\frac{Q_{i j}^{t}}{Q_{i j}^{0}}-\frac{Q_{i}^{t}}{Q_{i}^{0}}\right\}
\end{aligned}
$$

\section{HASIL DAN PEMBAHASAN}

\section{Analisis LQ}

Tabel 2

Hasil LQ Kabupaten Blitar Berdasarkan Lapangan Usaha (Harga Konstan) Tahun 2014-2019

\begin{tabular}{|l|r|r|r|r|r|r|r|l|}
\hline SEKTOR & $\mathbf{2 0 1 4}$ & $\mathbf{2 0 1 5}$ & $\mathbf{2 0 1 6}$ & $\mathbf{2 0 1 7}$ & $\mathbf{2 0 1 8}$ & $\mathbf{2 0 1 9}$ & $\begin{array}{l}\text { RATA- } \\
\text { RATA }\end{array}$ & SEKTOR \\
\hline $\begin{array}{l}\text { Pertanian, Kehutanan dan } \\
\text { Perikanan }\end{array}$ & 0.37 & 0.37 & 0.36 & 0.36 & 0.3 & 0.3 & 0.34 & NB \\
\hline Pertambangan dan Penggalian & 1.1 & 1.14 & 1.25 & 1.27 & 1.2 & 1.2 & 1.19 & $\mathrm{~B}$ \\
\hline Industri Pengolahan & 2.25 & 2.23 & 2.18 & 2.1 & 2.1 & 2.1 & 2.16 & $\mathrm{~B}$ \\
\hline Pengadaan Listrik dan Gas & 4.43 & 4.3 & 4.2 & 4.19 & 3.8 & 3.7 & 4.10 & $\mathrm{~B}$ \\
\hline $\begin{array}{l}\text { Pengadaan Air, Pengelolaan } \\
\text { Sampah, Limbah dan Daur } \\
\text { Ulang }\end{array}$ & & & & & & & & \\
\hline Konstruksi & 2.64 & 2.69 & 2.6 & 2.6 & 2.6 & 2.6 & 2.62 & $\mathrm{~B}$ \\
\hline $\begin{array}{l}\text { Perdagangan Besar dan } \\
\text { Eceran }\end{array}$ & 1.01 & 1 & 0.99 & 0.98 & 0.97 & 0.9 & 0.97 & $\mathrm{NB}$ \\
\hline Transportasi dan Pergudangan & 1.02 & 1.01 & 1 & 0.99 & 0.98 & 0.9 & 0.98 & $\mathrm{NB}$ \\
\hline $\begin{array}{l}\text { Penyediaan akomodasi dan } \\
\text { makanan }\end{array}$ & 2.35 & 2.36 & 2.35 & 2.31 & 2.2 & 2.1 & 2.278 & $\mathrm{~B}$ \\
\hline Informasi dan Komunikasi & 5.53 & 5.06 & 5.57 & 5.51 & 5.4 & 5.3 & 5.39 & $\mathrm{~B}$ \\
\hline Jasa Keuangan dan Asuransi & 1.13 & 0.89 & 0.88 & 0.86 & 0.8 & 0.8 & 0.85 & NB \\
\hline
\end{tabular}




\begin{tabular}{|l|r|r|r|r|r|r|r|l|} 
Real Estate & 0.89 & 0.88 & 0.87 & 0.86 & 0.84 & 0.84 & 0.86 & NB \\
\hline Jasa Perusahaan & 2.19 & 2.2 & 2.19 & 2.19 & 2.17 & 2.17 & 2.185 & B \\
\hline $\begin{array}{l}\text { Administrasi Pemerintahan, } \\
\begin{array}{l}\text { Pertanahan dan Jaminan } \\
\text { Sosial }\end{array}\end{array}$ & & & & & & & \\
\hline Jasa Pendidikan & 0.65 & 0.65 & 0.65 & 0.65 & 0.64 & 0.64 & 0.64 & NB \\
\hline $\begin{array}{l}\text { Jasa Kesehatan dan Kegiatan } \\
\text { Sosial }\end{array}$ & 0.63 & 0.63 & 0.63 & 0.63 & 0.62 & 0.62 & 0.62 & NB \\
\hline Jasa Lainnya & 0.77 & 0.78 & 0.78 & 0.78 & 0.77 & 0.77 & 0.77 & NB \\
\hline
\end{tabular}

Melihat hasil hitung di atas dapat dikatan bahwa potensi perekonomian yang ada di Kabupaten Blitar memiliki keunggulan yang dapat dikembangkan menjadi sektor unggulan Kabupaten. Sedangkan untuk sektor basis dan non basis dinilai dari apabila nilai LQ yang ada lebih tinggi dari satu atau (>1) maka sektor tersebut akan masuk kedalam sekot basis, berlaku sebaliknya untuk sektor non basis memiliki nilai kurang dari atau sama dengan satu $(</ \leq 1)$. Pada tabel tersebut dapat diketahui bahwa yang menjadi sektor basis atau unggulan dari Kabupaten Blitar adalah pertambangan \& penggalian, industri penglolaan, pengadaaan Istrik \& gas, pengadaan air sampah dan limbah daur ulang, transportasi dan pergudangan, penyediaan akomodasi dan makanan, serta jasa perusahaan. Sektor basis adalah sektor yang mmapu memenuhi permintaan barang dan jasa di pasar domestic maupun luar wilayah daerah tersebut, dari delapan sektor yang ada tertinggi adalah sektor jasa penyediaan akomodasi dan makanan. Oleh karena itu maka sektor yang menjadi sektor basis tersebut merupakan sektor yang dapat menjadi potensi bagi Kabupaten Blitar.

\section{Analisis Shift Share}

\section{Analisis Proportional Shift Componen (PS)}

Analisis ini digunakan untuk mengukur perubahan relatif naik atau turunnya suatu sektor perekonomian daerah terhadap sektor yang sama di tingkat provinsi atau nasional atau biasanya disebut juga dengan bauran industri (industry matrix)

Tabel 3

Hasil PS Kabupaten Blitar Berdasarkan Lapangan Usaha (Harga Konstan) Tahun 2014-2019

\begin{tabular}{|l|r|l|}
\hline SEKTOR & rata-rata & score \\
\hline Pertanian, Kehutanan dan Perikanan & -298681.575 & 0 \\
\hline Pertambangan dan Penggalian & 7411.526564 & 1 \\
\hline Industri Pengolahan & 17849.30222 & 1 \\
\hline Pengadaan Listrik dan Gas & -2749.870653 & 1 \\
\hline $\begin{array}{l}\text { Pengadaan Air, Pengelolaan Sampah, Limbah dan Daur } \\
\text { Ulang }\end{array}$ & 5374.018994 & 1 \\
\hline Konstruksi & 20122.76537 & 1 \\
\hline Perdagangan Besar dan Eceran & 810.3128128 & 1 \\
\hline Transportasi dan Pergudangan & 4897.365205 & 1 \\
\hline Penyediaan akomodasi dan makanan & 17017.36598 & 1 \\
\hline Informasi dan Komunikasi & -2709.61683 & 0 \\
\hline Jasa Keuangan dan Asuransi & -821.624538 & 0 \\
\hline Real Estate & 422.8740128 & 1 \\
\hline Jasa Perusahaan & -11324.1032 & 0 \\
\hline Administrasi Pemerintahan, Pertanahan dan Jaminan Sosial & 3126.988696 & 1 \\
\hline Jasa Pendidikan & & \\
\hline
\end{tabular}




\begin{tabular}{|l|r|l|}
\hline Jasa Kesehatan dan Kegiatan Sosial & 1743.353651 & 1 \\
\hline Jasa Lainnya & -1325.12814 & 0 \\
\hline
\end{tabular}

Berdasarkan tabel diatas dapat dijelaskan bahwasanya secara rata-rata nilai PS yang dimiliki Kabupaten Blitar memiliki keadaan yang cukup baik diakrenakan masih banyak sektor yang berada di nilai lebih dari 0 , dimana nilai tersebut memiki arti bahwa sektro tersebut memiliki pertunbuhan yang cepat, dari 17 sektor yang ada terdapat 11 sektor yang mempunyai pertumbuhan yang cepat sektor tersebut adalah sektor industri pengolahan, kontruksi, perdagangan besar dan eceran, penyediaan akomodasi \& makanan, informasi dan keungan, real estate, jasa perusahaan, administrasi pemerintahan, pertahanan dan jaminan sosial, jasa pendidikan, jasa kesehatan dan kegiatan sosial, jasa lainnya.

\section{Analisis PR}

TabeL. 4

Hasil PR Kabupaten Blitar Berdasarkan Lapangan Usaha (Harga Konstan) Tahun 2014-2019

\begin{tabular}{|c|c|c|}
\hline \multicolumn{2}{|l|}{ PR } & $\Delta \mathbf{Q i j}$ \\
\hline SEKTOR & $\begin{array}{l}\text { RATA- } \\
\text { RATA }\end{array}$ & score \\
\hline Pertanian, Kehutanan dan Perikanan & 382689.2 & 0 \\
\hline Pertambangan dan Penggalian & 51828.97 & 0 \\
\hline Industri Pengolahan & 162728.3 & 1 \\
\hline Pengadaan Listrik dan Gas & 921.5301 & 0 \\
\hline Pengadaan Air, Pengelolaan Sampah, Limbah dan Daur Ulang & 442.3272 & 0 \\
\hline Konstruksi & 111815.1 & 1 \\
\hline Perdagangan Besar dan Eceran & 221324.3 & 1 \\
\hline Transportasi dan Pergudangan & 15310.33 & 1 \\
\hline Penyediaan akomodasi dan makanan & 11481.44 & 1 \\
\hline Informasi dan Komunikasi & 77867.8 & 1 \\
\hline Jasa Keuangan dan Asuransi & 27286.78 & 0 \\
\hline Real Estate & 23944.86 & 1 \\
\hline Jasa Perusahaan & 4307.076 & 1 \\
\hline Administrasi Pemerintahan, Pertanahan dan Jaminan Sosial & 41377.31 & 0 \\
\hline Jasa Pendidikan & 50454.58 & 1 \\
\hline Jasa Kesehatan dan Kegiatan Sosial & 10243.22 & 1 \\
\hline Jasa Lainnya & 18364.72 & 1 \\
\hline
\end{tabular}

Dalam ketentuan tertulis apabila nilai $\mathrm{PR}<\Delta \mathrm{Qtij}$ maka sektor tersebut merupakan sektor yang mendorong pertumbuhan ekonomi provinsi, sebaliknya apa bila PR $>\Delta$ Qtij maka sektor tersebut memiliki dampak akan mengahambat pertumbuhan ekonomi provinsi. Dari tabel tesebut bisa diketahui bahwa industry pengolahan, kontruksi, perdagangan besar dan eceran, penyediaan akomodasi, inofrmasi dan komunikasi, jasa pendidikan, jasa kesehatan dan kegiatan sosial, serta jasa lalinnya merupakan sektor yang dapat mendorongn pertumbuhan ekonomi provinsisi, sedangkan sektor lain yang tersisa merupakan sektor yang cenderung mengahmbat pertumbuhan ekonomi provinsi. 


\section{Analisis Differential Shift Component (DS)}

\begin{tabular}{|c|c|c|}
\hline SEKTOR & Rata-rata & score \\
\hline Pertanian, Kehutanan dan Perikanan & 7124630.233 & 1 \\
\hline Pertambangan dan Penggalian & 978027.7674 & 1 \\
\hline Industri Pengolahan & 3161610.813 & 1 \\
\hline Pengadaan Listrik dan Gas & 17317.02853 & 1 \\
\hline Pengadaan Air, Pengelolaan Sampah, Limbah dan Daur Ulang & 8438.96134 & 1 \\
\hline Konstruksi & 2165053.309 & 1 \\
\hline Perdagangan Besar dan Eceran & 4290519.93 & 1 \\
\hline Transportasi dan Pergudangan & 298871.156 & 1 \\
\hline Penyediaan akomodasi dan makanan & 225512.1306 & 1 \\
\hline Informasi dan Komunikasi & 1533223.716 & 1 \\
\hline Jasa Keuangan dan Asuransi & 517900.9931 & 1 \\
\hline Real Estate & 461761.8017 & 1 \\
\hline Jasa Perusahaan & 82913.1657 & 1 \\
\hline Administrasi Pemerintahan, Pertanahan dan Jaminan Sosial & 780823.2824 & 1 \\
\hline Jasa Pendidikan & 971255.0348 & 1 \\
\hline Jasa Kesehatan dan Kegiatan Sosial & 197970.1017 & 1 \\
\hline Jasa Lainnya & 352900.5636 & 1 \\
\hline
\end{tabular}

Komponen ini bertujuan untuk mengukur besarnya Shift Regional Neto yang diakibatkan oleh sektor-sektor idnustri tertentu yang tumbuh lebih cepat atau bahkan lebih lambat di daerah yang di uji daripada tingkat provinsi yang disebabkan faktor Lokasional Intern. Sehingga dapat ditarik kesimpulan bahwa apabila hasil hitung DS > 0 maka menunjukkan bahwa sektor tersebut merupakan sektor yang memiliki keuntungan lokasional dan berlaku sebaliknya apabila $\mathrm{DS}<0$ maka sektor tersebut tidak memiliki keuntungan lokasional. Sesuai dengan tabel 5 keseluruhan dari sektor yang ada di Kabhpaten Blitar Memiliki Keuntungan Lokasional.

\section{PENUTUP}

Perkembangan ekonomi Kabupaten Blitar yang terlihat dari data yang penulis gunakan mulai dari tahun 2014 sampai dengan 2019 menunjukkan bahwa perekonomian kabupaten blitar cenderung meningkat namun dalam perkembangannya pertumbuhan ekonomi Kabupaten Blitar mengalami fluktuasi, yang didukung dengan sektor yang menjadi sektor unggulan dalam perekonomian, seperti sektor peneydiaan akomodasi dan konsumsi, dan beberapa sektor lainnya diharpkan nantinya dapat meningkatkan kesejahteraan masyarakat yang ada di wilayah Kabupaten Blitar.

1. Sesuai dengan hasil uji LQ dapat diketahui bahwasanya terdapat cukup banyak sektor potensial yang dapat dikembangkan oleh pemerintah daerah Kabupaten Blitar yang selama ini hanya mengandalkan sektor pertanian, namun dalam penelitian ini sektor pertanian merupakan bukan sebuah sektor basis yang ada di Kabupaten Blitar, hendaknya pemerintah bisa memulai melakukan pengembangan wilayah dan pengembangan sektor yang berpotensi seperti Industri Pengolahan serta penyediaan akomodasi dan makanan, sektor ini merupakan sektor yang paling berpotensi bagi Kabupaten Blitar menurut penulis.

2. Hasil analisis PS atau Proportional Shift Componen, Kabupaten Blitar memiliki sektorsektor yang memiliki rata-rata pertumbuhan dengan cepat dalam regional Kabuoaten Blitar karena nilai yang didapatkan merupakan nilai yang positif dimana empat sektor yang memiliki nilai tertinggi dan pertumbuhan yang cepat secara regional adalah sektor 
pertambangan dan penggalian, pengadaan lisrtrik dan gas, konstruksi, penyediaan akomodasi dan makanan.

3. Hasil analisis PR dapat ditarik kesimpulan bahwa rata-rata sektor ekonomi yang ada di wilayah Kabupaten Blitar merupakan sektor yang mendorong pertumbuhan ekonomi provinsi.

4. Hasil analsisis DS menunjukkan bahwa Kabupaten Blitar memiliki nilai yang positif hal ini didorong oleh faktor loaksional yang ada. Sehingga jika terus dikembangkan akan memberikan dampak yang baik bagi Kabupaten Blitar. 


\section{DAFTAR PUSTAKA}

Arsyad, Lincolin. 1999. "Ekonomi Pembangunan".Yogyakarta : BPFE UGM, Bagian Penerbitan STIE YKPN.

Blackman, A., M. Mathis and P. Nelson. (2001). The Greening of Development Economics: A Survey. (Discussion Paper). Washington: Resource for the Future.

Boediono. 1999. "Teori Pertumbuhan Ekonomi".

BPS Kabupaten Blitar. (2020) PDRB Atas Dasar Harga Konstan Menurut Lapangan Usaha (Juta Rupiah) (Juta Rupiah), 2010-2019 [Intenet], (https://blitarkab.bps.go.id/indicator/52/31/1/pdrb-atas-dasar-harga-konstanmenurut-lapangan-usaha-juta-rupiah-.html)

BPS Provinsi Jawa Timur. (2020) PDRB ADHK 2010 (Milyar Rupiah), 2010-2019, (https://jatim.bps.go.id/indicator/162/326/1/pdrb-adhk-2010.html )

Hess, $P$ and C. Ross. (1997). Economic Development Theories, Evidence and Policies. New York: The Dryden Press.

Sumihardjo, Tumar. (2008) Penyelenggaraan Pemerintahan Daerah Melalui Pengembangan Daya Saing Berbasis potensi Daerah. Bandung, Fokus Media. Suparmoko, M. (2002) Ekonomi Publik untuk Keuangan dan Pembangunan Daerah. Yogyakarta, Andi Offset.

Todaro, M. P. (2011). Pembangunan Ekonomi Edisi Kesebelas Jilid 1. Jakarta: Erlangga. 